\title{
Nutrition and Quality in Ornamental Plants ${ }^{(1)}$
}

\author{
ANTONIO EDUARDO FURTINI NETO(2), KARINA VOLPI FURTINI BOLDRIN( ${ }^{(3)}$, NEIL S. MATTSON(4)
}

\begin{abstract}
The visual quality of ornamental plants is necessarily linked to an adequate balance of nutrients. Plant height, shape and coloration are qualitative aspects of ornamental species, directly influenced by mineral nutrition, among other environmental aspects. The nutritional requirements of ornamental species are not yet well established, often resulting in inefficient use of chemical and organic fertilizers, without respecting the needs of each species as well as the proper time for application. This leads to the low quality of the final product, as well as high production costs, which justifies the importance of a nutritional knowledge of the species. In addition to plant nutrients, some elements not considered essential, such as silicon, may provide improvements in the quality of certain species, including ornamental plants. In this sense, this paper aims to compile information on the use of nutrients for ornamental species in order to contribute to the knowledge of the principal aspects of plant quality as relates to mineral nutrition.
\end{abstract}

Keywords: Nutrients, silicon, flowers, qualitative attributes.

\section{RESUMO}

Nutrição e qualidade em plantas ornamentais

A qualidade visual de plantas ornamentais está necessariamente atrelada a um balanço adequado de nutrientes. A altura das plantas, forma e coloração são aspectos qualitativos de espécies ornamentais, influenciados diretamente pela nutrição mineral, dentre outros aspectos ambientais. As exigências nutricionais de espécies ornamentais não são ainda bem estabelecidas, resultando muitas vezes no uso ineficiente de adubos químicos e orgânicos, sem respeitar as necessidades de cada espécie, bem como a época adequada de aplicação. Isso acarreta em baixa qualidade final dos produtos, além de custos elevados de produção, o que justifica a importância do conhecimento nutricional das espécies. Além dos nutrientes de plantas, alguns elementos não considerados essenciais, como o silício, podem proporcionar melhorias na qualidade de determinadas espécies, incluindo ornamentais. Nesse sentido, este trabalho visa a compilar informações sobre o uso de nutrientes por espécies ornamentais a fim de contribuir com o conhecimento dos principais aspectos da qualidade de plantas relacionados à nutrição mineral.

Palavras-chave: Nutrientes, silício, flores, atributos qualitativos.

\section{INTRODUCTION}

The floriculture agro-business has had significant growth in the last years in Brazil and in the world. The increasing demand for ornamental species, along with a greater requirement by the consumer market as to the quality and diversity of products, requires of the activity an adoption of technologies, a greater technical knowledge by producers, as well as an efficient system of transport and commercialization (PEREIRA et al., 2006; LANDGRAF and PAIVA, 2009). According to estimates by ABAFEP (2015), the flowers and plants agro-business has grown from $12 \%$ to $15 \%$ per year, well above the average of the national economy.

The attainment of products of high commercial quality and crops with greater productivity is associated with maximum efficiency in production (BENEDETTO, 2004). Furthermore, the quality of plant products is predominantly controlled by genetic factors, however it is also influenced by exogenous factors, including natural and anthropogenic (WANG et al., 2008; MARTINEZ-BALLESTRA et al., 2010). In this context, the mineral nutrition of plants is preponderant in the attainment of better quality agricultural products (MARSCHNER, 2012).

Plant quality is associated with physical properties that determine the appearance of plants, and chemicals, including the adequate balance of nutrients, in order to achieve the standards of commercialization and consumption (MARSCHNER, 2012). The visual quality of plants and productivity are particularly important for the ornamental species (VEATCH-BLOHM et al., 2012), and in general, determine the price of their commercialization.

Literature is not vast in relation to the mineral nutrition of ornamental plants, since floriculture is a relatively recent activity when compared to other commercial cultures. In many instances, producers rely on pre-established standards, and achieve excessive or insufficient fertilization, producing flowers with inferior quality and with an elevated cost.

\footnotetext{
(1) Received in 01/06/2015 and approved in 30/07/2015.

(2) Vale Institute of Technology (ITV), Belém-PA, Brazil.

(3) Federal University of Lavras, Department of Agriculture, Lavras-MG, Brazil. *Corresponding author: kkfurtini@yahoo.com.br

(4) Cornell University, Department of Plant Science, Ithaca-NY, United States.
} 
Moreover, often the use of nutrients based on an empirical approach and at unsuitable times, prevents the plants from exhibiting their full production potential (ALMEIDA et al., 2012). It is important to highlight that an adequate balance of nutrients, besides being related to high quality flower production, is also intimately linked to the resistance of the plants against pests and disease (MALAVOLTA, 2006; ZAMBOLIM et al., 2012).

This paper aims to contribute to the knowledge of aspects of mineral nutrition and its relation to the quality of ornamental plants.

\section{PLANT NUTRIENTS}

Plant nutrients are classified as such because they satisfy the criterion, direct or indirect of essentiality, established by Arnon and Stout (1939). The direct criteria assumes that the nutrient forms part of a compound or some crucial reaction in the plant metabolism, and the indirect is related to three characteristics: 1 - in the absence of the element, the plant does not complete its life cycle; 2 - the element can not be replaced by any other; 3- the effect of the element should not be related to environmental conditions, but should have a direct effect on the life of the plant. Thus, 17 chemical elements are classified as plant nutrients, classified into macronutrients: Nitrogen $(\mathrm{N})$, Phosphorus $(\mathrm{P})$, Potassium $(\mathrm{K})$, Calcium (Ca), Magnesium (Mg), Sulfur (S) and micronutrients: Boron (B), Chlorine (Cl), Copper $(\mathrm{Cu})$, Iron $(\mathrm{Fe})$, Manganese $(\mathrm{Mn})$, Molybdenum $(\mathrm{Mo})$, Nickel $(\mathrm{Ni})$, and Zinc $(\mathrm{Zn})$. Besides the mineral elements, Carbon $(\mathrm{C})$, Oxygen $(\mathrm{O})$ and Hydrogen $(\mathrm{H})$ are essential for metabolism and the plant life cycle.

Some elements may be directly related to plant metabolism, although without meeting the essentiality criterion. Cobalt (Co) is an essential element for legumes to actively participate in the fixation process $\mathrm{N}_{2}$ (MARSCHNER, 2012), while silicon ( $\mathrm{Si}$ ) is considered a useful element for performing beneficial functions, particularly in increasing the resistance of plants to biotic and abiotic factors (EPSTEIN, 1999). Selenium (Se), despite not having proved its essentiality for plants, acts as an antioxidant, protects against UV rays, regulates growth and protects against pathogens (KAUR et al., 2014).

All nutrients play a fundamental role in the life of the plant and the plant tends to present symptoms as a function of any deficiency, excess or imbalance in plants. The earliest changes in the plants occur at the molecular level, followed by the formation of compounds which prevent the processing of chemical reactions, with consequent changes in the tissues at the cellular level, and finally, the visible symptoms appear (MALAVOLTA, 2008), that is, when the symptoms of nutritional deficiency, excess or imbalance appear, the plant's metabolism is already seriously compromised. These symptoms may present characteristic features depending on the species, variety or genotype, the severity of the nutritional imbalance and environmental factors (ROSA et al., 2012). Furthermore, it can affect different parts of the plants. In the case of ornamental plants, besides the effects in production and productivity, the symptoms that visually affect the flower or inflorescence can significantly alter the final quality of the product, which is reflected in the final market price. The commercialization of flowers and ornamental plants is necessarily linked to better quality products (VEATCHBLOHM et al., 2012).

For most crops, nitrogen is the nutrient that is absorbed in greater quantity and accumulates in larger amounts in the dry mass of the plants. It is the main constituent of the earth's atmosphere; however plants absorb it and assimilate it mainly in the form of $\mathrm{NO}_{3}^{-}, \mathrm{e} \mathrm{NH}_{4}^{+}$, present in the soil solution (MARTINS et al., 2003). Besides these, organic forms of nitrogen contribute to plant nutrition, of which are present in the organic matter and in the form of peptides, proteins, amino acids and urea (NALSHOLM et al, 2009; MILLER and CRAMER, 2004). Its deficiency is generally quite dramatic for plants, causing widespread chlorosis and stunted habit, retarding and slowing growth, while the fruits become excessively colorful (EPSTEIN and BLOOM, 2006).

For most ornamental plants, potassium is the nutrient required in higher quantity. Potassium is directly related to the maintenance of the osmotic balance in plant cells, the process of the regulation of gas exchange and transpiration, enzyme activation, protein synthesis, photosynthesis, and stress resistance (BENITES et al, 2010;. MARSCHNER, 2012). It is a mobile element, translocated via phloem along with sucrose and which has great importance in the generation of the osmotic gradient between the source and the drain in the plant, especially in the flowering stage. At this stage, the flowers tend to be a strong drain, which can lead to a deficit of potassium, and consequently cause a decrease in sucrose levels with a possible adverse affect on flowering (BARBOSA et al., 2009). Under the condition of deficiency, the leaves often become dark green and necrotic tissues occur in general at the margin of the leaves.

For the gerbera crop, potassium is the nutrient required in the largest amount, especially during the flowering stage (MERCURY, 2002; LUDWIG et al, 2008; GUERRERO et al, 2012.). For pot chrysanthemum cv. Puritan, potassium applied via fertigation at a dose of $400 \mathrm{mg}$. $\mathrm{L}^{-1}$ provided a better quality plant in relation to the number of leaves, number of stems per pot, number and diameter of inflorescences (RODRIGUES et al., 2008), demonstrating the importance of the nutrient for the species.

It is important to consider that nutrient absorption occurs differently between the stages of growth and crop production, as well as accumulating in distinct forms in different organs of the plant. For the gerbera crop, the descending order of nutrient accumulation in leaves was $\mathrm{K}>\mathrm{N}>\mathrm{Ca}>\mathrm{Mg}>\mathrm{P}>\mathrm{S}$ at the end of vegetative and reproductive period, while for the flowers the order of absorption was $\mathrm{K}>\mathrm{N}>\mathrm{P}>\mathrm{Ca}>\mathrm{S}>\mathrm{Mg}$ (GUERRERO et al., 2012). For Aster ericoide, the extraction of nutrients from the soil obeyed the order of $\mathrm{K}>\mathrm{N}>\mathrm{P}>\mathrm{S}>\mathrm{Mg}>\mathrm{Ca}$ and micronutrients $\mathrm{Mn}>\mathrm{Fe}>\mathrm{Zn}>\mathrm{B}>\mathrm{Cu}(\mathrm{CAMARGO}$ et al., 2005), also showing differences between the nutritional requirements of the species. 
Often under field conditions, deficiencies can be severe enough to reduce production and harm the quality of the product, although visible symptoms are difficult to perceive (EPSTEIN and BLOOM, 2006), showing the importance of adequate and prior nutritional management in crops.

In the floriculture segment, plant height, as well as the height or length of the flower stalks, are of great importance, especially since they determine the price of their commercialization, according to qualitative aspects. In general, evaluating the literature on the subject, it is observed that the nutrients directly linked to the growth in height of ornamental plants are nitrogen, calcium, phosphorus, potassium, boron, magnesium and sulfur.

The growth in height of Iris germanica was reduced due to the omission of nitrogen, calcium, and phosphorus (ROSA et al., 2012). Nitrogen being present in many compounds of plant cells, including amino acids and nucleic acids, can cause growth deficiency in lower concentrations when required by the plant (TAIZ et al., 2015). The calcium in the plant has structural functions, being the component of the middle lamella, responsible for strengthening the cell wall and plant tissues. In plants deficient in elements, the activity of the polygalacturonase enzyme, responsible for the degradation of pectates, is increased, and the typical symptom is the disintegration of the cell walls and a collapse of the affected tissues, especially in the younger parts of the stem and petiole (HO and WHITE, 2005). Calcium is related to cell elongation and plant growth. The meristematic regions and the young leaves are the most affected by the deficiency of the element, in addition to the roots that are drastically reduced, with surface growth occurring at the expense of growth in depth (EPSTEIN and BLOOM, 2006). The function of phosphorus is directly linked to the nucleic acids, being part of the DNA as carriers of genetic information, and RNA, responsible for the translation of genetic information, where in both, phosphorous forms a bridge between ribonucleosides, to form macromolecules (MARSCHNER, 2012). Moreover, the phosphate group is also associated with the energy transfer process in the form of ATP. Low phosphorus concentrations in the cytoplasm cells are related to reduced plant growth, and concentrations less than $0.3 \mathrm{mM}$ prevent the complete growth of plants (MENGEL and KIRKBY, 2001).

For the torch-ginger crop (Etlingera elatior Jack), the omission of boron, followed by the omission of nitrogen, potassium and phosphorus, reduced the growth in height and production of biomass during the initial phase of cultivation (FRAZÃO et al., 2010). Boron deficiency results in reduced growth and plant deformities by preventing new cells from undergoing differentiation (MENGEL and KIRKBY, 2001). The cultivation of calla lily (Zantedeschia aethiopica) in a nutrient solution with different doses of boron, shows that the greatest plant height occurred with a dose of $1.05 \mathrm{mg} . \mathrm{L}^{-1}$ of the nutrient, and that the growth of the roots was drastically affected with the concentration of $0.05 \mathrm{mg} . \mathrm{L}^{-1}$ of boron (SOUZA et al., 2010). The low growth of plants with a potassium deficiency is mainly associated with the osmoregulatory function of the nutrient. For cell elongation to occur and hence plant growth there must be a relaxation of the cell wall realized by ATPase, which in turn is activated by potassium (MENGEL and KIRKBY, 2001). Furthermore, the increase of turgor pressure, resulting from water absorption in response to a decrease in osmotic potential through the absorption of potassium in the cell elongation process, is directly related to plant growth (FAQUIN, 2005). The growth of ornamental ginger (Zingiber spectabile) was limited by the omission of N, K, P, Ca and Mg (COELHO et al., 2012). The latter, being part of the chlorophyll molecule, as well as an enzymatic activator, is a co-factor of most phosphorylase enzymes such as ADP or ATP, resulting in less energy for the plant (MALAVOLTA, 2006). This may prevent the normal development of plants. Besides the omission of $\mathrm{N}, \mathrm{P}, \mathrm{K}, \mathrm{Ca}$ and $\mathrm{Mg}$ affecting the growth of ornamental banana (Musa velutina $\mathrm{H}$. Wendl. \& Drude), sulfur also reduced plant height (PINHO, 2007). Sulfur, by triggering and participating in a series of reactions in the plant, can promote a dramatic reduction in plant growth when at concentrations less than required by the crop.

The length of floral stems varies among species and cultivars. The determination of a standard size for commercialization takes into account both species and packaging sizes, as there are predetermined sizes for commercialization and consumer preference, mainly determined by the type of arrangement to be made (ALBUQUERQUE et al ., 2010). The fertilization of plants has a key role in determining the size of flower stalks produced. The length of inflorescences of the heliconia cultivar Golden Torch was mainly influenced by the omission of nitrogen and potassium, presenting an inferior size compared to those that received complete fertilization, as was also the case for those in which calcium and magnesium were omitted (CASTRO et al., 2007). In the case of ornamental plants, obtaining the maximum yield is less important than the quality of the final product.

Not only the lack but also the excess of nutrients is detrimental to the quality of ornamental plants. The observations of Boaretto and Morais (2010) using the information of Casarini and Folegati, show the effect of high doses of nitrogen (Figure 1) and potassium (Figure 2) on the length of rose stalks. The effect of higher potassium doses on reducing stem length was attributed to the increased electrical conductivity of the soil solution, caused by the nutrient source used. 


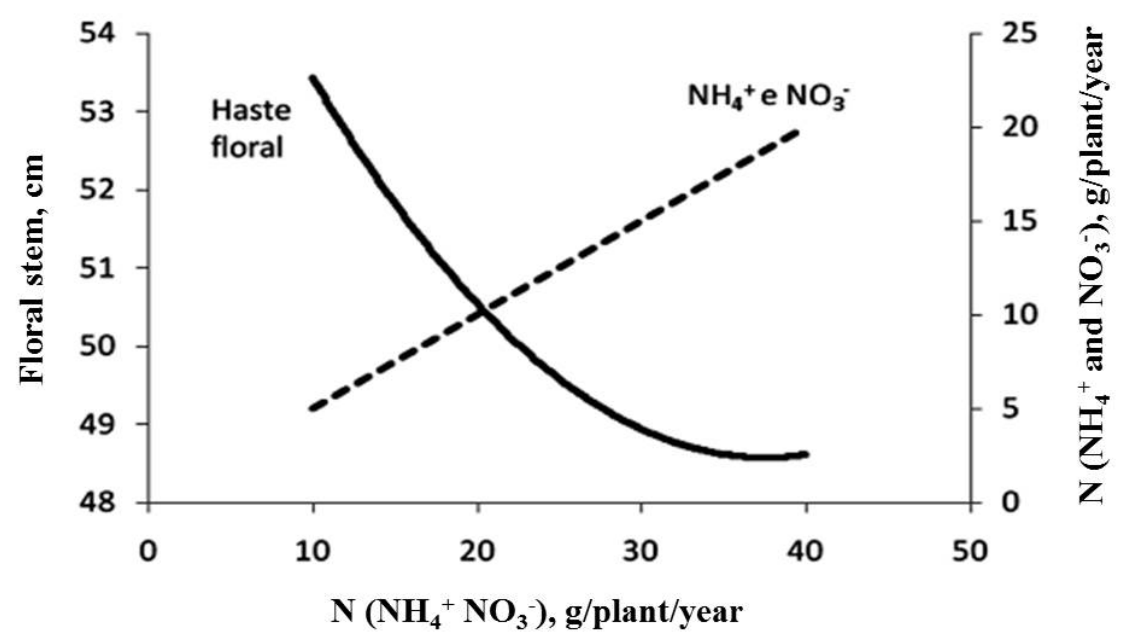

Figure 1. Doses of nitrogen and the concentration of ammonium and nitrate ions applied to the soil and the floral stem length of roses (data from CASARINI and FOLEGATTI, 2006, adapted by BOARETTO and MORAIS, 2010).

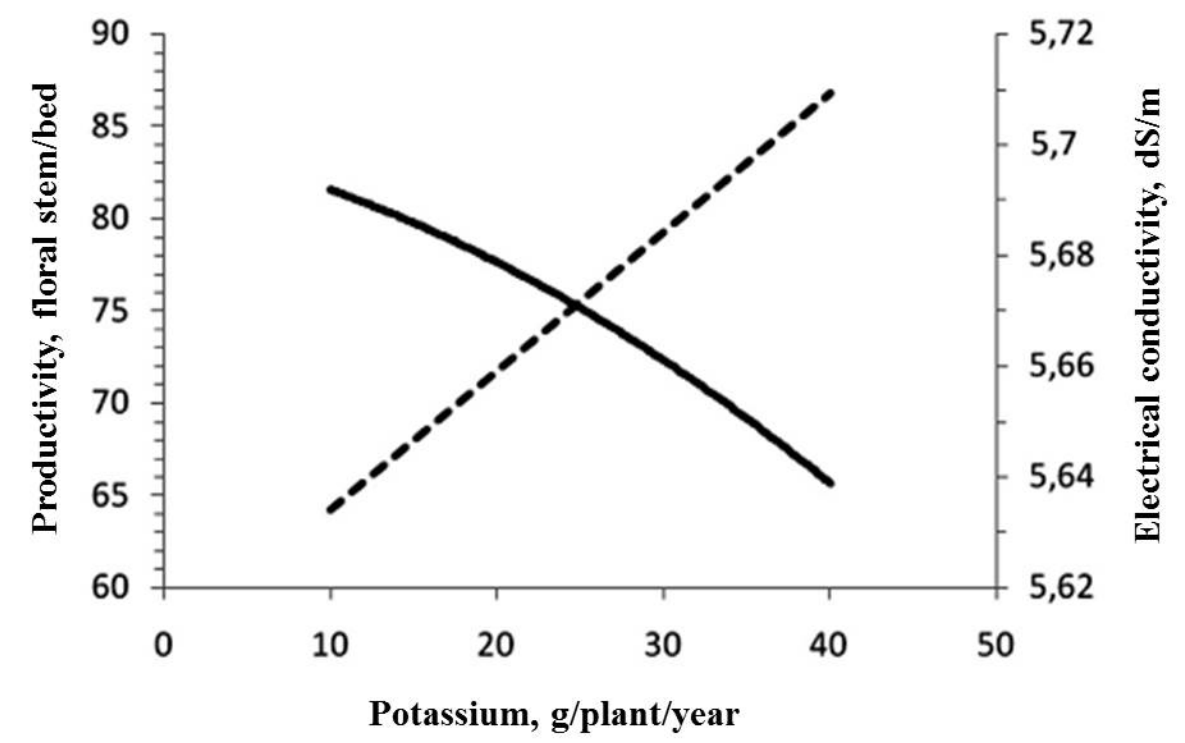

Figure 2. Effect of doses of potassium on the electrical conductivity of soil solution and on floral stem length (data from CASARINI and FOLEGATTI, 2006, adapted by BOARETTO and MORAIS, 2010).

Also in this context, producers have further used organic fertilization, in order to increase the quality of ornamental plants, including potted species and cutting species. Organic products such as manure and filter cake, among others, are being used as a source of nutrients. Each product has different concentrations of nutrients, mainly determined by the feed composition and metabolism of the animal from which the by-product originates, when obtained from animals, or the concentration of nutrients in the plant, for example. The use of good quality cattle manure can meet part of the plants in macronutrient needs, due to the supply of nutrients (ARAUJO et al., 2007), especially potassium, whose levels reach higher values in the soil through the continued use of organic matter (CARMARGO, 1984; RAIJ et al., 1985). The filter cake, a byproduct of the alcohol industry, has significant amounts of calcium, nitrogen and phosphorus, in high concentration and slow release forms, which facilitates its use (MORGADO et al., 2000;. SANTOS et al, 2005). Heliconias cultivar Golden Torch, grown with organic, mineral and organo-mineral fertilizer, presented satisfactory results in the length of the flower stem, amongst other characteristics, when they received a combination of mineral and organic fertilizers (ALBUQUERQUE et al., 2010). The use of cattle manure in the substrate during the cultivation of the calla lily (Zantedeschia aethiopica) promoted improvements in the development and production of the crop, its use being recommended in the cultivation substrate (FURTINI, 2010). Almeida et al. (2012) did not observe significant differences to the growth of the same species cultivated 
with NPK doses and cattle manure, which was justified by the reserve of nutrients present in the cultivation soil, as well as the evaluation only having taken place in the first year of cultivation. It is important to highlight that the effect of organic fertilizers is not only restricted to their supply of nutrients, but also to their fundamental role in improving soil properties, such as the increase in CTC and improvement of moisture retention.

The shape of plants or inflorescences is predominantly influenced by the genetic base of the plants, however, the lack of or excess of nutrients can cause deformations in parts of the plant (MARSCHNER, 2012). Plants deficient in phosphorus tend to have delayed flowering, and deformities of the flower buds, seeds and fruits (MALAVOLTA, 2006).

The coloring of ornamental plants plays a major role in the acquisition of products by consumers (MARSCHNER, 2012). The color of plants, especially leaves, can be directly related to nutrient deficiency.

Plants deficient in nitrogen tend to present yellowing, initially in older leaves due to a reduced synthesis of chlorophyll (MALAVOLTA, 2006). Inflorescences of the heliconia cultivar Golden Torch, produced with the omission of nitrogen, presented a paler coloration in relation to inflorescences produced with complete fertilization (CASTRO et al., 2007). Potassium deficient plants exhibit chlorosis followed by necrosis on the tips and edges of leaves, initially occurring in older leaves (FAQUIN, 2005). Figure 3 illustrates the potassium deficiency in calla lily plants (FURTINI, 2010). Similar results were found for ornamental ginger and ornamental banana (PINHO, 2007; COELHO et al., 2012).
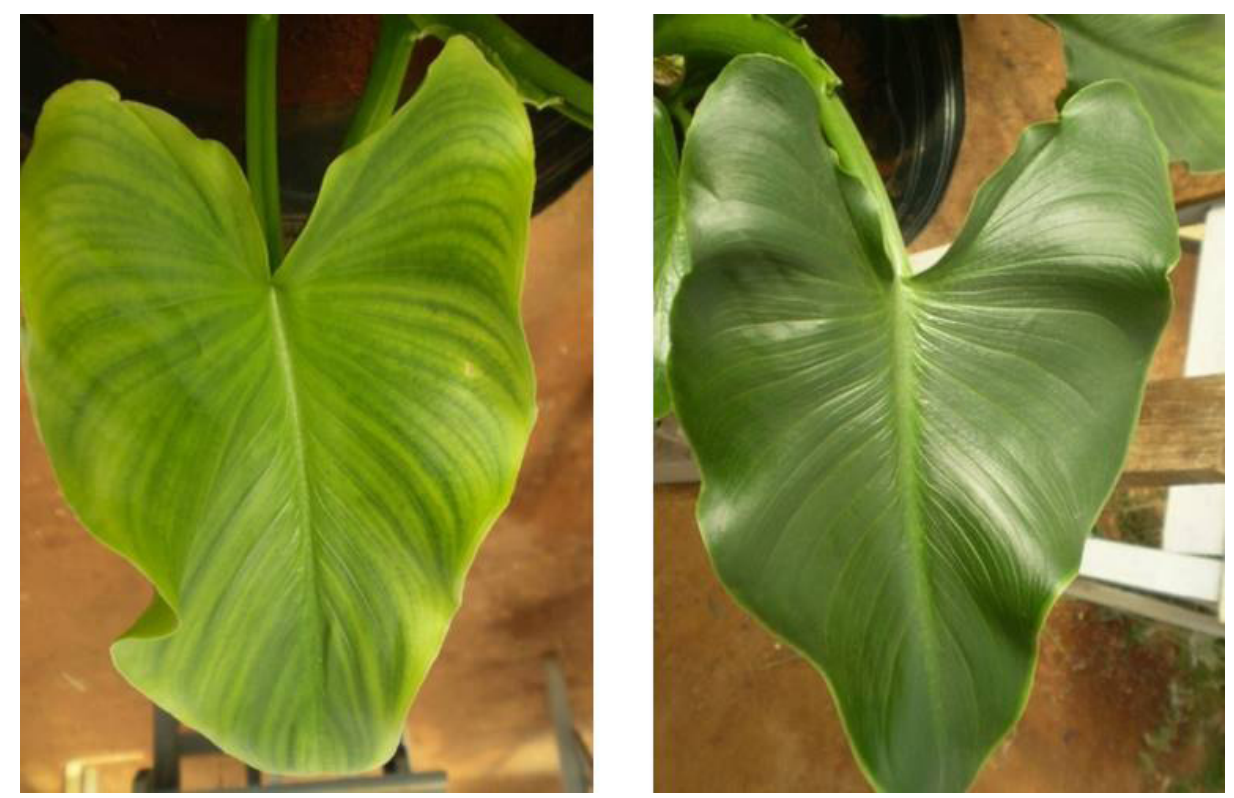

Figure 3. Appearance of calla lily leaves grown under potassium omission (left) and with application of $420 \mathrm{mg} \mathrm{dm}^{-3}$ potassium (right) on the substrate.

Calcium deficiency occurs initially in young leaves due to the low mobility of the nutrient in the plant, and they tend to show chlorosis followed by necrosis (FAQUIN, 2005). Similar results were reported for ornamental ginger and torch-ginger (FRAZÃO et al, 2010; COELHO et al, 2012.).

Plants deficient in magnesium present internerval chlorosis in older leaves and those deficient in sulfur present widespread chlorosis of the leaf blade, initially in the young leaves (FAQUIN, 2005).

Plants with a phosphorus deficiency present a purplish coloration of the leaves, which is associated with a greater synthesis of anthocyanins, responsible for darker coloration (TAIZ et al., 2015). This occurs because with a phosphorus deficiency, the synthesis of carbohydrate is reduced, which increases the concentrations of sugars, and thus stimulates protein synthesis (MARSCHNER, 2012).
Similar symptoms were found in Iris germanica (ROSA et al., 2012). However, these symptoms were not observed in ornamental ginger plants deficient in phosphorus (COELHO et al., 2012), indicating that there are differences in symptoms between distinct species.

An interesting characteristic related to flower color is in the change in colororation depending on the $\mathrm{pH}$ of the soil or the means of cultivation. Hydrangea plants (Hydrangea macrophylla), when in acid soils tend to have a blue color, while those grown in alkaline soil have pink flowers (YOSHIDA et al, 2008; YOSHIDA et al. 2009). In addition to $\mathrm{pH}$, flower color is also related to the complex formation between anthocyanins and heavy metals in soil, such as aluminum. The soil $\mathrm{pH}$ is also linked to the incidence of diseases in various species, existing diseases of high $\mathrm{pH}$ plants and low pH diseases (ZAMBOLIM et al., 2012). Often this effect is related to a greater or lesser availability 
of nutrients for the growth of pathogenic microorganisms, due to the alteration of soil $\mathrm{pH}$.

\section{SILICON}

Silicon ( $\mathrm{Si})$, the second most abundant element in the earth's crust, accumulates in most plants grown on soil (EPSTEIN, 1999). Si is not recognized as an essential plant nutrient by higher plants because they are able to grow to maturity in hydroponic solutions without the element (EPSTEIN, 1999). However, due to numerous reports of benefits for plant growth and development, specifically under stress conditions, and its consistent presence at concentrations equivalent to those of macronutrients, Si has been designated a "quasi-essential element" (EPSTEIN, 1999). In this section we discuss Si uptake and reported benefits for floriculture crops (cut flowers, potted plants, and bedding plants).

\subsection{Silicon uptake, substrate availability, and sup- plementation}

Plant Si content depends on both soil Si availability and the inherent capacity of roots to absorb $\mathrm{Si}$. Si content varies greatly among plant species, ranging from $0.1-10 \%$ by dry weight (EPSTEIN, 1999). Within angiosperms, monocots including the family Poaceae represent $\mathrm{Si}$ accumulators. Some dicots, including species of Fabaceae, Cucurbitaceae, and Asteraceae also accumulate relatively high Si levels ( $>1 \%$ by dry weight). Many dicots species including members of the Solanaceae, are low Si accumulators (HODSON et al., 2005). Si content also varies within genotypes of a species (DEREN, 2001).

$\mathrm{Si}$ is absorbed from the soil solution by the roots as soluble orthosilicic acid $\left(\mathrm{H}_{4} \mathrm{SiO}_{4}\right)$ which is further translocated to the shoot via the xylem. Upon xylem transport to aboveground organs, silicic acid is further concentrated through loss of water (transpiration) and polymerizes mostly in subepidermal layers as solid, amorphous silica (silicon dioxide, $\mathrm{SiO}_{2}$ ) (EPSTEIN, 1999). Si availability in the growth medium is an important factor affecting $\mathrm{Si}$ accumulation. The majority of $\mathrm{Si}$ in soil is present in insoluble form as the crystalline structure in sand, silt and clay particles. While $\mathrm{Si}$ is abundant in soils, the content of plant available orthosilicic acid varies greatly, averaging 0.1-0.6 mM (EPSTEIN, 1994). Globally, most weathered soils in tropical ecoregions (such as Ultisols and Oxisols) are deficient in plant available Si (SAVANT et al., 1997). Besides Si limitations in field production systems, hydroponic systems and many soilless substrates (such as peat, perlite, vermiculite, and rockwool) contain little soluble Si (VOOGT and SONNEVELD, 2001). Depending on the water source, irrigation water may contain trace amounts of Si (VOOGT and SONNEVELD, 2001). Therefore, the potential exists to enhance plant quality stress responses through Si supplementation of hydroponic, container-grown, and field crops. Several forms and application methods of supplemental Si have been used for floriculture crops including potassium silicate $\left(\mathrm{KSiO}_{3}\right)$, sodium silicate $\left(\mathrm{NaSiO}_{3}\right)$ applied as substrate drenches or incorporated in the substrate, substrate incorporated rice husk ash (KAMENIDOU et al. 2008), substrate incorporated rice hulls (LOCKE et al., 2010) substrate incorporated wollastonite $\left(\mathrm{CaSiO}_{3}\right)$ (WILLIAMS, 2012), and foliar applied orthosilicic acid (DĘBICZ and WRÓBLEWSKA, 2011). Si can be added to the fertigation program, however soluble Si forms a precipitate with other fertilizer stock solutions so a separate stock tank and injector should be utilized or alternatively $\mathrm{Si}$ applications can be made as a weekly drench when not applying other fertilizers.

$\mathrm{Si}$ is taken up by a broad range of floriculture species (FRANTZ et al., 2008; MATTSON and LEATHERWOOD, 2010; HOGENDORP et al., 2012). Of twenty-one bedding plant cultivars examined by Mattson and Leatherwood, 2010, all cultivars accumulated appreciable amounts of leaf Si when grown in soilless substrate, with a range of $211 \mathrm{mg} \cdot \mathrm{kg}^{-1}$ for Petunia hybrida to $2606 \mathrm{mg} \cdot \mathrm{kg}^{-1}$ for Argyranthemum frutescens. Weekly $100 \mathrm{mg} \cdot \mathrm{L}^{-1}$ potassium silicate drenches significantly increased leaf Si concentration of 11 cultivars as compared to control plants, with a leaf $\mathrm{Si}$ increase of 13 to $145 \%$. Leaf Si concentration of Zinnia elegans varied from $5200 \mathrm{mg} \cdot \mathrm{kg}^{-1}$ for control plants to $17000 \mathrm{mg} \cdot \mathrm{kg}^{-1}$ for plants that received weekly drenches of $200 \mathrm{mg} \cdot \mathrm{L}^{-1}$ potassium silicate (KAMENIDOU et al., 2009).

\subsection{Si effects on plant morphology quality}

Si supplementation has been reported to affect plant morphology and quality characteristics of many different floriculture crops but the impacts are species and cultivar specific and depend on the form of Si used. Increased stem diameters have been reported in response to Si supplementation for Chrysanthemum $\times$ morifolium 'Backwang' (MOON et al., 2008), Rosa hybrid 'Pinocchio' (HWANG et al., 2005), and Vinca major 'Wojo's jem' (MATTSON and LEATHERWOOD, 2010) all growing in soilless substrate. Weekly foliar sprays of $500 \mathrm{mg}$.L-1 sodium silicate increased the fresh weight and diameter of soil grown Paeonia lactiflora 'Hongyanzhenghui' flower stem and flower (ZHAO et al., 2013). Increased mechanical strength of flower stems was observed at this Si application concentration and this may be due to increased cell wall thickness of sclerenchyma cells and increased lignin content of flower stems. Si supplementation can improve cut flower quality (increased flower diameter and stem/flower peduncle diameter) of Helianthus annuus 'Ring of Fire' (KAMENIDOU et al., 2008), Zinnia elegans 'Oklahoma Formula Mix' (KAMENIDOU et al., 2009), and Gerbera hybrid 'Acapella' (KAMENIDOU et al., 2010). However, their findings demonstrate that morphological responses depend greatly on the Si form and concentration. For example, substrate incorporated potassium silicate (at $140 \mathrm{~g} \cdot \mathrm{m}^{-3} \mathrm{Si}$ ) resulted in increased stem height of Zinnia, weekly potassium silicate drenches (100-200 mg. $\left.\mathrm{L}^{-1}\right)$ delayed anthesis and reduced stem height. Similarly, weekly foliar sprays of sodium silicate at 50 or $100 \mathrm{mg} . \mathrm{L}^{-1}$ hastened anthesis and increased flower peduncle diameter and height and flower diameter; however, foliar sprays at $150 \mathrm{mg} . \mathrm{L}^{-1}$ delayed anthesis, shortened stems and caused flower deformation. Three foliar sprays of orthosilicic acid increased the number of lateral shoots and inflorescences in Sanvitalia speciosa 'Sun- 
bini', Verbena 'Patio Blue', and Portulaca umbraticola 'Duna Red' (DĘBICZ and WRÓBLEWSKA, 2011). Three cultivars of Chrysanthemum $\times$ morifolium in a coir-based substrate exhibited beneficial morphological and growth responses to potassium silicate applied via daily subirrigation (SIVANESAN et al., 2013). Applications of $50 \mathrm{mg} \cdot \mathrm{L}^{-1}$ Si increased plant height, stem diameter, chlorophyll index, number of flowers, flower diameter, and shoot dry weight as compared with controls. However, in many cases application of $100 \mathrm{mg} . \mathrm{L}^{-1} \mathrm{Si}$ caused a reduction in the measured parameters, in some cases even reducing quality as compared with controls. For example, plant height of 'Gaya Pink' was 49.52 , and $46.0 \mathrm{~cm}$ with 0.50 , and $100 \mathrm{mg} . \mathrm{L}^{-1}$ $\mathrm{Si}$, respectively. In addition, older leaves exhibited necrotic lesions with Si application and incidence of this disorder was greater at increased Si concentration. Research by Lim et al. (2012) also suggests that silicon may be a beneficial mineral element in plant tissue culture. Seeds of Begonia semperflorens and Viola $\times$ wittrockiana were grown in vitro in a medium containing $0,100,200$, or $300 \mathrm{mg} . \mathrm{L}^{-1} \mathrm{Si}$ from $\mathrm{K}_{2} \mathrm{SiO}_{3}$. Shoot fresh weight of Begonia was greatest at 200 mg. $\mathrm{L}^{-1} \mathrm{Si}$, while chlorophyll index of Viola 'Matrix White Blotch' was greater with Si supplementation.

\subsection{Plant biotic/abiotic stress tolerance}

There is a growing awareness that silicon ( $\mathrm{Si}$ ) added to the substrate can improve plant tolerance to various abiotic and biotic stresses. While it is not fully understood the mechanisms for this protection appear to include both physical protection against stresses (when silica is deposited in the sub-epidermal layer) as well as biochemical activity of silicic acid (which mediates the plant's internal responses to stress via differential gene expression (MA and YAMAJI, 2008).

Regarding abiotic disorders, Si foliar sprays were effective in reducing symptoms of bract edge burn, a calcium deficiency, in poinsettia (Euphorbia pulcherrima 'Supjibi Red') (McAVOY and BIBLE, 1996). Antioxidant enzyme expression of Salvia splendens after 2 days of heat stress $\left(35^{\circ} \mathrm{C}\right)$ was significantly enhanced by potassium silicate supplementation with $100 \mathrm{mg} . \mathrm{L}^{-1} \mathrm{Si}$ suggesting Si may mediate heat tolerance response (Soundararajan et al, 2014). In addition SDS-PAGE revelated three protein bands which responded differentially to Si treatment. Cut flower Rosa hybrid grown with elevated salt stress $(40 \mathrm{mM} \mathrm{NaCl}$ as compared with $0.8 \mathrm{mM} \mathrm{NaCl}$ control) did not exhibited an increase in the number of marketable flower stems when supplied with $56 \mathrm{mg} . \mathrm{L}^{-1} \mathrm{Si}$ from potassium silicate as compared with control (8.4 mg.L-1 $\mathrm{Si}$ (SAVVAS et al., 2007). However, the $56 \mathrm{mg} . \mathrm{L}^{-1} \mathrm{Si}$ solution increased the vegetative fresh weight of both the low and high salt treatments, and increased the number of marketable stems in the low salt treatment. Copper $(\mathrm{Cu})$ toxicity is sometimes a problem in greenhouses due to the use of electrolytic $\mathrm{Cu}$ for disinfection of irrigation water (ZHENG et al., 2004) and its use as a microbiocide. In a study comparing $\mathrm{Si}$ supplementation affects in high (e.g. zinnia) vs. low (e.g. snapdragon) Si accumulating plants, mitigation of $\mathrm{Cu}$ metal toxicity was observed in both plants in response to Si application, but was much more pronounced in the former (FRANTZ et al., 2011).

Si supplementation has been reported to improve disease tolerance of floriculture crops in several studies. Si reduced incidence of black spot in shrub roses (Rosa hybrid) (GILLMAN et al., 2003) and powdery mildew in miniature potted roses (DATNOFF et al., 2006; Larsen, 2008). Calcium silicate supplementation decreased Botrytis infection of Helianthus annuus 'Ring of Fire' (KAMENIDOU et al., 2002). Potassium silicate as well as three other commercially available Si fertilizers reduced naturally occurring disease incidence of Chrysanthemum 'Shinro' when examined 14 days after transplanting (JEONG et al., 2012). Potassium silicate drenches as well as two organic substrate amendments containing Si, rice (Oryza sativa) hulls and chopped Miscanthus x giganteum) straw reduced incidence of powdery mildew on Zinnia elegans up to 8 weeks after inoculation with the disease (LOCKE et al., 2010). However, Si supplementation did not reduce powdery mildew severity of Gerbera jamesonii 'Snow White' (MOYER et al., 2008).

Regarding Si mediated resistance to insect pests, potassium silicate drenches at $200 \mathrm{mg} . \mathrm{L}^{-1} \mathrm{Si}$ or greater reduced leafminer (Liriomyza trifolii) emergence from infected Chrysanthemum plants (PARELLA et al., 2007). A 40 to $57 \%$ reduction in naturally occurring aphid (Macrosiphoniellas anborni) colonies was noted in Si treated Chrysanthemum plants as compared with control plants without Si (JEONG et al., 2012). Potassium silicate drenches led to modest yet significant reductions in fecundity of green peach aphids (Myzus persicae) feeding on Zinnia elegans (RANGER et al., 2009). Si treatments led to an increased level of three phenolic compounds as well as guaiacol peroxidase suggesting that defense related compounds may be involved in the reduced aphid fecundity. However, Si does not appear to be always beneficial for tolerance against insects. Neither foliar spray $\left(50 \mathrm{mg} . \mathrm{L}^{-1} \mathrm{Si}\right)$ or drenches $(0$, $100,400,800$, and 1,600 mg. $\mathrm{L}^{-1} \mathrm{Si}$ ) with potassium silicate negatively impacted citrus mealybug (Hemiptera: Pseudococcidae) feeding on Solenstemon scutellarioides plants (HOGENDORP et al, 2009).

In summary, while not considered an essential mineral element for higher plants, Si supplementation has been reported to enhance plant quality/morphology and stress tolerance in many floriculture crops. The findings appear to be species/cultivar specific and dependent on whether the irrigation water or substrate already contains $\mathrm{Si}$ as a byproduct as well as on the form and rate of applied Si. Therefore, in commercial settings, small scale trials with $\mathrm{Si}$ should be undertaken before adopting $\mathrm{Si}$ as part of the fertilizer program. 


\section{REFERENCES}

ABAFEP - ASSOCIAÇÃO BRASILEIRA DO AGRONEGÓCIO DE FLORES E PLANTAS. Disponível em <http://www.abafep.com.br/dadosSetor.php.> Acesso em 21 de julho de 2015.

ALBUQUERQUE, A.W., ROCHA, E.S., COSTA, J.P.V., FARIAS, A.P., BASTOS, A.L. Produção de helicônia Golden Torch influenciada pela adubação mineral e orgânica. Revista Brasileira de Engenharia Agrícola e Ambiental, Campina Grande, v.14, n.10, p.1052-1058, 2010.

ALMEIDA, E.A.F., DUARTE, P.D.O., FRAZÃO, J.E.M., SANTOS, F.H.S., RESENDE, F.A., CAMPOS, M.L. Produção de copo-de-leite em resposta à adubação com NPK e esterco bovino. Revista Brasileira de Horticultura Ornamental, v.18, n.2, p.129-134, 2012.

ARAÚJO, E. N.; OLIVEIRA, A.P.; CAVALCANTE, L.F.; PEREIRA, W.E.; BRITO, N.M.; NEVES, C.M.L.; SILVA, É.É. Produção do pimentão adubado com esterco bovino e biofertilizante. Revista Brasileira de Engenharia Agrícola e Ambiental, Campina Grande, v. 11, n. 5, p. 466-470, 2007.

ARNON, D.I., STOUT, P.R. The essentiality of certain elements in minute quantities for plants with special reference to copper. Plant Physiology, v.14, p.371-375, 1939.

BARBOSA, J.G., BARBOSA, M.S., MUNIZ, M.A., GROSSI, J.A. Nutrição mineral e adubação de plantas ornamentais. Informe Agropecuário, v.30, p.16-21, 2009.

BENEDETTO, A. Cultivo intensivo de espécies ornamentales. 1ed. Buenos Aires: Editorial Facultad de Agronomía, 2004. 288 p.

BENITES, V.M., CARVALHO, M.C.S., RESENDE, A.V., POLIDORO, J.C., BERNARDI, A.C.C., OLIVEIRA, F.A. Potássio, cálcio e magnésio. In: PROCHNOW, L.I.; CASARIN, V.; STIPP, S.R.(Ed). Boas Práticas para Uso Eficiente de Fertilizantes. Volume 2. Piracicaba: International Plant Nutrition Institute, 2010. p.137-191.

BOARETTO, A.E., MORAES, M.F. Contribuição da nutrição adequada para qualidade dos alimentos. In: PRADO, R.M. et al. (Ed). Nutrição de plantas: diagnose foliar em hortaliças. Jaboticabal: FCAV, CAPES, FAPESP, CNPq. 2010. 376p.

CAMARGO, L. S. As hortaliças e seu cultivo. Campinas: Fundação Cargill, 1984. p. 28-29.

CAMARGO, M.S., MELLO, S.C., ANTI, G.R., CARMELLO, Q.A.C. Crescimento e absorção de nutrientes pelo Aster ericoides cultivado em solo sob estufa. Horticultura Brasileira, Brasília, v.23, n.2, p.271274, 2005.
CASTRO, A.C.R. de, COSTA, V.L.A.S. da, CASTRO, M.F.A. de, ARAGÃO, F.A.S. de, WILLADINO, L.G. Hastes florais de helicônia sob deficiência de macronutrientes. Pesquisa Agropecuária Brasileira, Brasília, v.42, n.9, p.1299-1306, 2007.

COElHO, V.A.T., RODAS, C.L., COELHO, L.C., CARVALHO, J.G., ALMEIDA, E.F.A., FIGUEIREDO, M.A. Caracterização de sintomas visuais de deficiências de macronutrientes e boro em plantas de gengibre ornamental. Revista Brasileira de Horticultura Ornamental, v. 18, n.1, p.47-55, 2012.

DATNOFF, L.E., NELL, T.A., LEONARD, R.T., RUTHERFORD, B.A. Effect of silicon on powdery mildew development on miniature potted rose. Phytopathology, v.96, S28, 2006.

DĘBICZ, R., WRÓBLEWSKA, K. The effect of silicon foliar application on the development of seasonal ornamental plants. Part I: Sanvitalia speciosa 'Sunbini', Verbena 'Patio Blue' and Portulaca umbraticola 'Duna Red'. Acta Agrobotanica, v.64, n.4, p.99-106, 2011.

DEREN, C. Plant genotype, silicon concentration, and silicon-related responses. In: DATNOFF L, SNYDER G, KORNDORFER, G. Silicon in agriculture. Amsterdam: Elsevier, 2001. p.149-158.

EPSTEIN, E. The anomaly of silicon in plant biology. Proceeding of the National Academy of Sciences of the United States of America, v.91, p.11-17, 1994.

EPSTEIN, E. Silicon. Annual Review of Plant Physiology and Plant Molecular Biology, v. 50, p.641646, 1999.

EPSTEIN, E., BLOOM, A. Nutrição Mineral de Plantas. Londrina: Editora Planta. 2006. 403p.

FAQUIN, V. Nutrição de plantas. Lavras: UFLA/ FAEPE, 2005.183p.

FRANTZ, J.M., KHANDEKAR, S., LEISNER, S. Silicon Differentially Influences Copper Toxicity Response in Silicon-accumulator and Non-accumulator Species. Journal of the American Society for Horticultural Science, v.136, n.5, p.329-338, 2011.

FRANTZ, J.M., LOCKE, J.C., DATNOFF, L., OMER, M., WIDRIG, A., STURTZ, D., HORST, L., KRAUSE, C.R. Detection, distribution, and quantification of silicon in floricultural crops utilizing three distinct analytical methods. Communications in Soil Science and Plant Analysis, v.39, p.2734-2751, 2008.

FRAZÃO, J.E.M.; PINHO, P.J.; CARVALHO, G.C.; ALMEIDA, E.F.A. Caracterização da deficiência nutricional simples e conjunta de boro e zinco em 
plantas de antúrio (Anthurium andraeanum). Belo Horizonte: EPAMIG, 2009. Circular Técnica, 69.

FURTINI, K.V. Desenvolvimento de copo-de-leite cultivado em substratos com diferentes fontes de potássio. 2012.71p. Dissertação (Mestrado em Agronomia/ Fitotecnia) - Universidade Federal de Lavras, Lavras.

GILLMAN, J.H., ZLESAK, D.C., SMITH, J.A. Applications of potassium silicate decrease black spot infection in Rosa hybrid 'Meipelta' (Fuchsia Meidiland). HortScience, v.38, p.1144-1147, 2003.

GUERRERO, A.C.; FERNANDES, D.M.; LUDWIG, F. Acúmulo de nutrientes em gérbera de vaso em função de fontes e doses de potássio. Horticultura Brasileira, v.30, p.201-208, 2012.

HO, L.C.; WHITE, P.J. A Cellular Hypothesis for the Induction of Blossom-End Rot in Tomato Fruit. Annals of Botany, v.95, p.571-581, 2005.

HODSON, M.J, WHITE, P.J., MEAD, A., BROADLEY, M.R. Phylogenetic variation in the silicon composition of plants. Annals of Botany, v. 96, n.6, p.1027-1046, 2005.

HOGENDORP, B. K., CLOYD, R.A., SWIADER, J.M. Effect of silicon-based fertilizer applications on the reproduction and development of the citrus mealybug (Hemiptera: Pseudococcidae) feeding on green coleus. J. Economic Entomology, v.102, n.6, p.2198-2208, 2009.

HOGENDORP, B.K., CLOYD, R.A., SWIADER, J.M. Determination of silicon concentration in some horticultural plants. HortScience, v.47, p.1593-1595, 2012.

HWANG, S.J., PARK, H.M., JEONG, B.R. Effects of potassium silicate on the growth of miniature rose 'Pinocchio' grown on rockwool and its cut flower quality. Journal of the Japanese Society for Horticultural Science, v.74, n.3, p.242-247, 2005.

JEONG, K.J., CHON,Y.S., HA, S.H., KANG, H.K., YUN, J.G. Silicon application on standard chrysanthemum alleviates damages induced by disease and aphid insect. Korean Journal of Horticultural Science and Technology, v.30, n.1, p.21-26, 2012.

KAMENIDOU, S., CAVINS, T.J., MAREK, S. Silicon supplementation affects greenhouse produced cut flowers. 2002. M.S. Thesis, Oklahoma State University, Stillwater, Oklahoma.

KAMENIDOU, S., CAVINS, T.J., MAREK, S. Silicon supplements affect horticultural traits of greenhouseproduced ornamental sunflowers. HortScience, v.43, p.236-239, 2008.
KAMENIDOU, S., CAVINS, T.J., MAREK, S. Evaluation of silicon as a nutritional supplement for greenhouse zinnia production. Scientia Horticulturae, v.119, n.297-301, 2009.

KAMENIDOU, S., CAVINS, T.J., MAREK, S. Silicon supplements affect floricultural quality traits and elemental nutrient concentrations of greenhouse produced gerbera. Scientia Horticulturae, v.123, n.390-394, 2010.

KAUR, N., SHARMA, S., KAUR, S., NAYYAR, H. Selenium in agriculture: a nutrient or contaminant for crops? Archives of Agronomy and Soil Science, v.60, n.12, p.1593-1624, 2014.

LANDGRAF, P.R.C.; PAIVA, P.D.O. Agronegócio da floricultura brasileira. Magistra, Cruz das Almas, v.21, n.4, p.253-261, 2009.

LARSEN, A.K. Less mildew in pot roses with silicon. FlowerTECH, v.11, p.18-19, 2008.

LIM, M.Y., LEE, E.J., JANA, S., SIVANESAN, I., JEONG, B.R. Effect of potassium silicate on growth and leaf epidermal characteristics of begonia and pansy grown in vitro. Korean Journal of Horticultural Science and Technology, v.30, n.5, p.579-585, 2012.

LOCKE, J.C., ALTLAND, J.E., FRANTZ, J. Suppression of Zinnia Powdery Mildew in the Greenhouse with Silicon-containing Media Amendments. Journal of Phytopathology, v.100, S74, 2010.

LUDWIG, F., FERNANDES, D.M., MOTA, P.R.D., VILLAS BÔAS, R.L. Macronutrientes em cultivares de gérbera sob dois níveis de fertirrigação. Horticultura Brasileira, v.26, p.68-73, 2008.

MA,J.F., YAMAJI, N. Functions and transport of Silicon in plants. Cellular and Molecular Life Sciences, v.65, p.3049-3057, 2008.

MALAVOLTA, E. Manual de nutrição mineral de plantas. São Paulo: Editora Agronômica Ceres, 2006. $638 \mathrm{p}$.

MALAVOLTA, E. O futuro da nutrição de plantas, tendo em vista aspectos agronômicos, econômicos e ambientais. Informações Agronômicas, n.121, p.1-10, 2008.

MARSCHNER, H. Mineral nutrition of higher plants. 3ed. London: Academic Press, 2012. 651p.

MARTINS, C.R., PEREIRA, P.A.P., LOPES, W.A., ANDRADE, J.B. Ciclos globais de carbono, nitrogênio e enxofre: a importância na química da atmosfera. Química Nova, n.5, p.28-41, 2003. 
MARTINEZ-BALESTRA，M.C., DOMINGUEZ-PERLES, R., MORENO, D.A., MURIES, B., ALCARAZLÓPEZ, C., BASTÍAS, E., GARCÍA-VIGUERA, C., CARVAJAL, M. Mineral in plant food: effect of agricultural practices and role in human health. A review. Agronomy for Sustainable Development, v.30, p.295$309,2010$.

MATTSON, N.S., LEATHERWOOD, W.R. Potassium silicate drenches increase leaf silicon content and affect morphological traits of several floriculture crops grown in a peat-based substrate. HortScience, v.45, p.43-47, 2010.

McAVOY, R.J., BIBLE, B.B. Silica sprays reduce the incidence and severity of bract necrosis in poinsettia. HortScience, v.31, p.1146-1149, 1996.

MENGEL, K., KIRKBY, E.A. Principles of plant nutrition. 5ed. Dordrecht: Kluwer Academic Publishers, 2001. 864p.

MERCURY, G. Gerbera cultivation in greenhouse. De Kwakel: Schreurs, 2002. 206p.

MILLER, A.J., CRAMER, M.D. Root nitrogen acquisition and assimilation. Plant Soil, v.274, p.1-36, 2004.

MOON, H.H., BAE, M.J., JEONG, B.R. Effect of silicate supplemented medium on rooting of cutting and growth of chrysanthemum. Flower Research Journal, v.16, p.107-111, 2008.

MORGADO, I.F., CARNEIRO, J.G.A., LELES, P.S.S., BARROSO, D.G. Resíduos agroindustriais prensados como substratos para a produção de mudas de cana-deaçúcar. Scientia Agrícola, v.57, n.4, p.709-712, 2000.

MOYER, C., PERES, N.A., DATNOFF, L.E., SIMONNE, E.H., DENG, Z. Evaluation of silicon for managing powdery mildew on gerbera daisy. Journal of Plant Nutrition, v.31, p.2131-2144, 2008.

NASHOLM, T., KIELLAND, K., GANETEG, U. Uptake of organic nitrogen by plants. New Phytologist, v.182, p.31-48, 2009.

PARELlA, M.P., COSTAMAGNA, T.P., KASPI, R. The addition of potassium silicate to the fertilizer mix to suppress Liriomyza leafminers attacking chrysanthemums. Acta Horticulturae, v.747, p.365-369, 2007.

PEREIRA, C. M. M. A.; MELO, M. R.; DIAS, P. B. Cadeia de produção de rosas na região de Barbacena, Estado de Minas Gerais. Informações Econômicas, São Paulo, v.36, n. 7, p.22-31, 2006.

PINHO, P.J. Deficiências nutricionais em bananeira ornamental (Musa velutina h. Wendl. \& Drude): Alterações químicas e morfológicas e caracterização de sintomas visuais. Lavras-MG. Universidade Federal de Lavras, 2007. 147p. Tese (Doutorado em Ciência do Solo).

RAIJ, B. van; CANTARELLA, H.; QUAGGIO, J.A.; FURLANI, A.M.C. Recomendações de Adubação e Calagem para o Estado de São Paulo, 2ed. Revisada e ampliada. Campinas, Instituto Agronômico \& Fundação IAC, 1997. 285p. (Boletim Técnico, 100).

RANGER, C. M., SINGH, A.P., FRANTZ, J.M., CANAS, L., LOCKE, J.C., REDING, M.E., VORSA, N. Influence of silicon on resistance of Zinnia elegans to Myzus persicae (Hemiptera: Aphididae). Environmental Entomology, v.38, n.1, p.129-136, 2009.

ROSA, Y.B.C.J., SILVA, E.F., FONSECA, I.C., SILVA, J.F., ROSA JUNIOR, E.J., ROSA, D.B.C.J., SORGATO, J.C. Crescimento e sintomas de deficiência nutricional em Iris germanica L. decorrentes da omissão de macronutrients. Revista Agrarian, Dourados, v.5, n.17, p.303-309, 2012.

RODRIGUES, T.M., RODRIGUES, C.R., PAIVA, R., FAQUIN, V., PAIVA, P.D.O., PAIVA, L.V. Níveis de potássio em fertirrigação interferindo no crescimento/ desenvolvimento e qualidade do crisântemo. Ciência e Agrotecnologia, Lavras, n.4, p.1168-1175, 2008.

SANTOS, A.C.P., BALDOTTO, P.V., MARQUES, P.A.A., DOMINGUES, W.L., PEREIRA, W.L. Utilização de torta de filtro como substrato para a produção de hortaliças. Colloquium Agrariae, v.1, n.2, p.1-5, 2005.

SAVANT, N.K., SNYDER, G.H., DATNOFF, L.E. Silicon management and sustainable rice production. Advances in Agronomy, v.58, p.151-199, 1997.

SAVVAS, D., GIZAS, G., KARRAS, G., LYDAKIS-SIMANTIRIS, N., SALAHAS, G., PAPADIMITRIOU, M., TSOUKA, N. Interactions between silicon and NaCl-salinity in a soilless culture of roses in the greenhouse. European Journal of Horticultural Science, v.72, p.73-79, 2007.

SIVANESAN, I., SON, M.S., SONG, J.Y., JEONG, B.R. Silicon supply through the subirrigation system affects growth of three chrysanthemum cultivars. Horticulture, Environment, and Biotechnology, v.54, n.1, p.14-19, 2013.

SOUNDARARAJAN, P., SIVANESAN, I., JANA, S., JEONG, B.R. Influence of silicon supplementation on the growth and tolerance to high temperature in Salvia splendens. Horticulture, Environment, and Biotechnology, v.55, n.4, p.271-279, 2013.

SOUZA, R. R., PAIVA, P.D.O., CARVALHO, J.G., ALMEIDA, E.F.A., BARBOSA, J.C.V. Doses de boro no desenvolvimento de copo-de-leite em solução nutritiva. Ciência e Agrotecnologia, Lavras, v.34, n.6, p.1396-1403, 2010. 
TAIZ, L., ZEIGER, E., MOLLER, I.M., MURPHY, A. Plant Physiology and Development. Sixth Edition. 2015. $761 \mathrm{p}$.

VEATCH-BLOHM, M.E., MALINOWSKI, M., KEEFER, D. Leaf water status, osmotic adjustment and carbon assimilation in colored calla lilies in response to saline irrigation. Scientia Horticulturae, Amsterdam, v. 144, p. 65-73, 2012.

VOOGT, W., SONNEVELD, C. Silicon in horticultural crops grown in soilless culture. In: DATNOFF, L.E., SNYDER, G.H., KORNDÖRFER, G.H. (EDS.). Silicon in Agriculture. Amsterdam: Elsevier Science B.V., 2001. p.115129.

WANG, Z., LI, S.X., MALHI, S. Effects of fertilization and other agronomic measures on nutritional quality of crops. Journal of the Science of Food and Agriculture, v.88, p.7-23, 2008.

WILLIAMS, K.A. Research report: new twists on old ideas offer advances in greenhouse fertilizers and root media. GrowerTalks, v.75, n.10, p.54-60, 2012.
YOSHIDA, K., ITO,D., SHNKAI, Y., KONDO, T. Change of color and components in sepals of chameleon hydrangea during maturation and senescence. Phytochemistry, Oxford, v.69, n.18, p.3159-3165, 2008.

YOSHIDA, K., MORI, M., KONDO, T. Blue flower color development by anthocyanis: from chemical structure to cell physiology. Natural Products Reports, Cambridge, v.26, n.7, p.857-964, 2009.

ZAMBOLIM, L.; VENTURA, J.A.; ZANÃO JÚNIOR, L.A. Efeito da nutrição mineral no controle de doenças de plantas. Viçosa: UFV, 2012. 321p.

ZHAO, D., ZHAOJUN, H., TAO, J., HAN, C. Silicon application enhances the mechanical strength of inflorescence stem in herbaceous peony (Paeonia lactiflora Pall.). Scientia Horticulturae, Amsterdam, v.151, p.165-172, 2013.

ZHENG, Y.B., WANG, L.P., DIXON, M.A. Response to copper toxicity for three ornamental crops in solution culture. Hortscience, v.39, n.5, p.1116-1120, 2004. 
